\title{
Antibiotic Resistance and Virulence Gene Profiles in Staphylococci Isolated from Cattle with Mastitis
}

\author{
Mehmet Onur GÖKDAĞ Alper ÇíFTCI* \\ Ondokuz Mayls University, Faculty of Veterinary Medicine, Department of Microbiology, Samsun, Turkey
}

How to cite: Çiftci, A. \& Gökdağ, M.O. (2020). Antibiotic Resistance and Virulence Gene Profiles in Staphylococci Isolated from Cattle with Mastitis. J. Anatolian Env. and Anim. Sciences, 6(3), 395-402.

Atıf yapmak için: Çiftci, A. \& Gökdağ, M.O. (2020). Mastitisli Sı̆̆ırlardan İzole Edilen Stafilokoklarda Antibiyotik Direnci ve Virülens Gen Profilleri. Anadolu Çev. ve Hay. Dergisi, 6(3), 395-402.

: https://orcid.org/0000-0001-8370-8677 iD: https://orcid.org/0000-0003-4325-3772
*Corresponding author's: Alper ÇiFTCI

Ondokuz Mayıs University, Faculty of Veterinary Medicine, Department of Microbiology, Samsun, Turkey

\: aciftci@omu.edu.tr

\begin{abstract}
Staphylococcus spp. are the important bacterial agents of subclinical and clinical mastitis cases. This study was aimed to determine the vancomycin resistances, antibacterial resistance profiles, some virulence genes, and pheno- and genotyping of staphylococci from mastitis. For this aim, 121 staphylococcal isolates were analyzed. The identifications of isolates were confirmed with PCR for being Staphylococcus spp. and Staphylococcus aureus. The antibiotic resistance patterns were determined by Kirby-Bauer Disc Diffusion Tests and according to the resistance profiles, the isolates were antibiotyped. The vancomycin resistance genes were determined by PCR for investigating the vanA, vanH, vanR, vanS, vanZ, van $Y$ and vanX genes. The vancomycin resistant isolates were genotyped with RAPD-PCR. The nuc gene was detected in 86 of 121 staphylococcal isolates examined and named as Staphylococcus aureus. The remaining 35 isolates were defined as Staphylococcus spp. S. aureus isolates were found to be resistant to penicillin G, amoxicillin/clavulanic acid, oxacillin, tetracycline, cefoperazone, teicoplanin, vancomycin and trimethoprim-sulfamethoxazole at 50\% (43/86), 40.7\% (35/86), $34.9 \%$ (30/86), $23.3 \%$ (20/86), $22.1 \%$ (19/86), $18.6 \%(16 / 86) 10.5 \%(9 / 86)$ and $8.1 \%(7 / 86)$ respectively. On the other hand, 4 (11.4\%) of 35 Staphylococcus spp. isolates were resistant to penicillin G, $3(8.6 \%)$ to amoxicillin/clavulanic acid, $2(5.7 \%)$ to trimethoprim-sulfamethoxazole, $1(2.9 \%)$ to oxacillin, cefoperazone, teicoplanin, while all isolates were sensitive to vancomycin and tetracycline. Of the $9 S$. aureus isolates that were phenotypically resistant to vancomycin, $v a n A$ gene was detected in 2 and $v a n R$ gene in 3 isolates. Multiple resistances to three or more antibiotics were determined in 42 of $86 \mathrm{~S}$. aureus isolates. In addition, coa gene was detected in $61(70.9 \%)$ of 86 S. aureus isolates. 10 different gene polymorphisms were detected in coa gene positive isolates. While the spa gene was determined in all $S$. aureus isolates, it was revealed that they had 4 spa gene polymorphisms. Nine different genotypes with a similarity between $51-75 \%$ were detected in the genotyping of vancomycin resistant 9 isolates. In conclusion, multiple antibiotic resistance rates in $S$. aureus isolates investigated were found to be important for mastitis treatment. The results obtained from this study show that milk and dairy products containing these factors pose a public health risk due to the determination of vancomycin resistance in mastitisderived Staphylococcus strains.
\end{abstract}

Keywords: Bovine, coa, mastitis, RAPD-PCR, spa, Staphylococcus, vancomycin resistance.

\section{Mastitisli Sığırlardan İzole Edilen Stafilokoklarda Antibiyotik Direnci ve Virülens Gen Profilleri}

Öz: Staphylococcus spp. subklinik ve klinik mastitis olgularının önemli bakteriyel etkenleridir. $\mathrm{Bu}$ çalışmanın amacı, mastitis kaynaklı stafilokokların vankomisin dirençlerini, antibakteriyel direnç profillerini, bazı virülans genlerini ve feno- ve genotiplendirmesini belirlemektir. Bu amaçla 121 stafilokok izolatının analizi yapılmıştır. İzolatların Staphylococcus spp. ve Staphylococcus aureus olmak üzere identifikasyonları PCR ile ve antibiyotik direnç paternleri de Kirby-Bauer Disk Difüzyon Testleri ile belirlendi. İzolatlar direnç profillerine göre antibiyotiplendirildi. VanA, vanH, vanR, vanS, vanZ, vanY ve vanX genlerinin PCR ile

${ }^{[*]}$ This study was produced from the master thesis. 
araştırılması sonucunda vankomisin direnç genleri belirlendi. Vankomisine dirençli izolatlar, RAPD-PCR ile genotiplendirildi. İncelenen 121 stafilokok izolatının 86'sında nuc geni saptandı ve Staphylococcus aureus olarak identifiye edildi. S. aureus izolatlarının penisilin G, amoksisilin/klavulanik asit, okzasilin, tetrasiklin, sefaperazon, teikoplanin, vankomisin ve trimetoprim-sulfamethoxazole sirasiyla \%50 (43/86), \%40.7 (35/86), \%34,9 (30/86), \%23,3 (20/86), \%22.1 (19/86), \%18,6 (16/86) \%10,5 (9/86) ve \%8,1 (7/86) oranında dirençli bulundu. 35 adet Staphylococcus spp.'nin $4(\% 11,4)$ 'ü penisilin G'ye, $3(\% 8,6)$ 'ü amoksisilin/klavulanik aside, $2(\% 5,7)$ 'si trimetoprim-sülfometaksazole, $1(\% 2,9)$ 'i oksasilin, sefaperazon, teikoplanine direnç gösterirken, tüm izolatlar vankomisin ve tetrasikline duyarlıydı. Vankomisine fenotipik olarak dirençli olan $9 \mathrm{~S}$. aureus izolatından 2'sinde vanA, 3 'ünde vanR geni saptandı. 86 S. aureus izolatının 42'sinde üç veya daha fazla antibiyotiğe karşı çoklu direnç belirlendi. Ayrıca $86 S$. aureus izolatının $61(\% 70.9)$ 'inde coa geni tespit edildi. coa geni pozitif izolatlarda 10 farklı gen polimorfizmi tespit edildi. Tüm $S$. aureus izolatlarında spa geni belirlenirken, 4 spa gen polimorfizmi görüldü. Vankomisine dirençli 9 izolatın genotiplendirilmesinde \%51-75 arasında benzerlik gösteren dokuz farklı genotip tespit edildi. Sonuç olarak, araştırılan S. aureus izolatlarında çoklu antibiyotik direnç oranları mastitis tedavisi için önemli bulunmuştur. $\mathrm{Bu}$ çalışmadan elde edilen sonuçlar, bu faktörleri içeren süt ve süt ürünlerinin mastitis kaynaklı Staphylococcus suşlarında vankomisin direncinin belirlenmesi nedeniyle halk sağlığı açısından risk oluşturduğunu göstermektedir.

Anahtar kelimeler: Coa, inek, mastitis, RAPD-PCR, spa, Staphylococcus, vankomisin direnci

\section{INTRODUCTION}

Bovine mastitis is a costly and multifactorial disease for businesses and producers due to reduced milk production, increased treatment costs, culling and mortality rates in dairy farms. More than 130 different types of microorganisms have been isolated in cow milk with mastitis. Staphylococcus aureus might be present in both subclinical and clinical mastitis cases as one of the most common chronic mastitis factors (Monistero et al., 2020). It has been reported that there are many factors involved in virulence of $S$. aureus strains that cause mastitis. Coagulase, DNAse, protein A, toxins (enterotoxins, leukotoxins, toxic shock syndrome toxin, exulsive toxin, etc.), hemolysins, fibrinolysins, and biofilm formation were responsible for the formation of $S$. aureus originated mastitis (Momtaz et al., 2010; Kot et al., 2016)

Although the discovery of effective agents used in the prevention and treatment of infections caused by bacteria and other pathogenic microorganisms is one of the most important developments in modern medicine, substances with anti-infective potential have actually been used for thousands of years. With the introduction of penicillin in the $1940 \mathrm{~s}$, the mortality rate due to staphylococcal infections decreased rapidly. However, shortly after, $S$. aureus strains started to produce penicillinase enzyme and developed penicillin resistance and these resistant strains spread rapidly. In the late 1950s, approximately $50 \%$ of strains became resistant to penicillin. At the same dates, strains of $S$. aureus, which showed multiple resistance to tetracycline, chloramphenicol and erythromycin, were reported (Schwarz et al., 2018). Methicillin, the first semisynthetic penicillinase resistant antimicrobial agent, entered clinical use in 1959. Two years later, in 1961, the first methicillinresistant $S$. aureus (MRSA) isolates were reported from the UK (Jevons, 1961) and later became a problem in Europe in the 1960s and the USA in the 1970s (Hartstein \& Mulligan, 1986). MRSA strains showing multiple resistance to antibiotics spread all over the world in the late 1980s and 1990s (Schmitz \& Jones, 1997). MRSA is still among the most common nosocomial pathogens in hospitals of various sizes all over the world. Due to the increase in infections due to multiple resistant MRSA strains, vancomycin has been used for the treatment of staphylococcal nosocomial infections for the last 25 years. Vancomycin resistance was reported in clinical isolates of coagulase negative staphylococci in 1987 (Schwalbe et al., 1987). Clinical failures due to the selection of teicoplanin resistant isolates were reported after treatment of S.aureus infections with teicoplanin in 1990 (Kaatz et al., 1990). The emergence of MRSA isolates with reduced sensitivity to the vancomycin of Japan, USA and France in 1997 is very worrying (CDCP, 1997; Hiramatsu et al., 1997). These strains are resistant to most other antimicrobial agents and are isolated from patients who do not respond to vancomycin therapy. Vancomycin is a narrow-spectrum bactericidal antibiotic that was first isolated from Streptomyces orientalis on Borneo Island in 1956. Shortly after its isolation, it was purified in 1956 and entered clinical use. It lost importance after use of meticillin due to the impurity the preparations used in the first years and frequency of side effects, but gained importance with the first reporting of a methicillin-resistant $S$. aureus isolate in 1961 and the increasing MRSA infections since 1982.

In this study, it was aimed to investigate the vancomycin resistances, antibacterial resistance profiles, 
some virulence genes, pheno- and genotyping of staphylococci from mastitis.

\section{MATERIAL AND METHOD}

Bacterial isolates: Within the scope of the study, 121 Staphylococcal isolates from bovine mastitis milks were examined. For the molecular identification, DNAs were extracted from fresh colonies by boiling method as described previously and their concentrations were equalized to $50 \mathrm{ng} /$ microliter (Sezener et al., 2019). PCR was performed for the identification of isolates as Staphylococcus spp. and/or S. aureus. S. aureus specific nuc gene (279 bp) and Staphylococcus spp. specific 16S rRNA gene (756 bp) were investigated (Table 1) (Çiftci et al., 2009).

Table 1. Oligonucleotide primer sequences used for identification.

\begin{tabular}{llc}
\hline & Oligonucleotide sequence (5'-3') & Band size (bp) \\
\hline Staph756F & AAC TCT GTT ATT AGG GAA GAA CA & 756 \\
Staph756R & CCA CCT TCC TCC GGT TTG TCA CC & \\
nuc 1 & GCG ATT GAT GGT GAT ACG GTT & 279 \\
nuc 2 & AGC CAA GCC TTG ACG AAC TAA AGC & \\
\hline
\end{tabular}

Antibiotic sensitivity tests: Antibiotic susceptibility tests of all isolates were performed under the conditions recommended by the Clinical and Laboratory Standards Institute (2013) by Kirby Bauer disc diffusion technique. For this purpose, standard antibiotic discs [oxacillin $(10 \mu \mathrm{g})$, vancomycin $(30 \mu \mathrm{g})$, teicoplanin (30 $\mu \mathrm{g})$, trimethophrim-sulfamethoxazole $(25 \mu \mathrm{g})$, tetracycline (30 $\mu \mathrm{g})$, penicillin $\mathrm{G}(10 \mu \mathrm{g})$, cefoperazone $(75 \mu \mathrm{g})$, amoxicillin-clavulonic acid $(20 / 10 \mu \mathrm{g})]$ were used. The results were evaluated as sensitive (S), intermediate (I), and resistant (R) (CLSI, 2018).

Determination of vancomycin resistance level: Broth microdilution technique recommended by the Clinical and Laboratory Standards Institute (CLSI, 2018) was used to determine the minimal inhibition concentrations (MIC) of vancomycin resistance in staphylococcal strains. MIC values for staphylococci against vancomycin were evaluated as $4 \mu \mathrm{g} / \mathrm{ml}$ for susceptible, $8-16 \mu \mathrm{g} / \mathrm{ml}$ for intermediate susceptible (VISA), $\geq 32 \mu \mathrm{g} / \mathrm{ml}$ for resistant (VRSA).

Genotypic determination of vancomycin resistance: Vancomycin resistance genes of isolates which were determined to be resistant to vancomycin by diffusion method were determined by PCR. PCR was performed for these genes using specific oligonucleotides for the vanA, vanH, vanR, vanS, vanZ, vanY, and vanX genes (Table 2) in the vanA gene cluster of staphylococcal isolates (Dezfulian et al., 2012). Amplification products were visualized with UV transilluminator after $1.5 \%$ agarose gel electrophoresis.
Determination of virulence genes: Coagulase (coa) and protein A (spa) virulence genes of all isolates were determined by PCR. coa and spa genes presences and polymorphisms were detected by the method reported by Ciftci et al. (2009). The polymorphisms of the isolates were determined according to the band sizes displayed, and the isolates were typed with respect to their band sizes.

Table 2. Oligonucleotide primer sequences used to identify vancomycin resistance genes.

\begin{tabular}{|c|c|c|c|c|}
\hline Primer & & Oligonucleotide sequence (5'-3') & Band size (bp) & Innealing $\left({ }^{\circ} \mathrm{C}\right)$ \\
\hline vanRI & F & AGCGATAAAATACTTATTGTGGA' & \multirow{2}{*}{645} & \multirow{2}{*}{53} \\
\hline $\operatorname{van} R 2$ & $\mathrm{R}$ & CGGATTATCAATGGTGTCGTT & & \\
\hline vanS1 & $\mathrm{F}$ & TTGGTTATAAAATTGAAAAATAA & \multirow{2}{*}{1155} & \multirow{2}{*}{47} \\
\hline vanS2 & $\mathrm{R}$ & TTAGGACCTCCTTTTATC & & \\
\hline vanHl & $\mathrm{F}$ & ATCGGCATTACTGTTTATGGAT & \multirow{2}{*}{943} & \multirow{2}{*}{55} \\
\hline $\mathrm{vanH} 2$ & $\mathrm{R}$ & TCСТTTCAAAATCCAAACAGTTT & & \\
\hline vanAl & F & ATGAATAGAATAAAAGTTGCAATAC & \multirow{2}{*}{1029} & \multirow{2}{*}{52} \\
\hline vanA2 & $\mathrm{R}$ & CCCCTTTAACGCTAATACGAT & & \\
\hline $\operatorname{vanXI}$ & $\mathrm{F}$ & ATGGAAATAGGATTTACTTT & \multirow{2}{*}{609} & \multirow{2}{*}{46} \\
\hline $\operatorname{van} X 2$ & $\mathrm{R}$ & TTATTTAACGGGGAAATC & & \\
\hline $\operatorname{van} Y 1$ & $\mathrm{~F}$ & ATGAAGAAGTTGTTTTTTTTA & \multirow[b]{2}{*}{912} & \multirow[b]{2}{*}{47} \\
\hline $\operatorname{van} Y 2$ & $\mathrm{R}$ & TTACCTCCTTGAATTAGTAT & & \\
\hline $\operatorname{vanZl}$ & $\mathrm{F}$ & TTATCTAGAGGATTGCTAGC & \multirow{2}{*}{454} & \multirow{2}{*}{51} \\
\hline $\operatorname{vanZ2}$ & $\mathrm{R}$ & AATGGGTACGGTAAACGAGC & & \\
\hline
\end{tabular}

Genotyping and phylogenetic analysis: RAPDPCR was performed using M13 (5'-AAG TAA GTG ACT GGG GTG AGC G-3') primer for genotyping of vancomycin resistant isolates (Findık et al., 2011). The similarities and numbers of the bands among RAPD patterns were determined based on the Dice similarity coefficient. To create a dendrogram that graphed genetic relatedness among isolates, "Unweighted Pair Group Method with Arithmetic Averages (UPGMA)" was employed using CHEF-DR $®$ III, Quantity One $\AA$ Software (Bio-Rad Laboratories, Hercules, CA).

\section{RESULTS}

Genotypical identification of isolates: It was determined to contain Staphylococcus spp. specific $16 \mathrm{~S}$ rRNA gene of all isolates and confirmed to be Staphylococcus spp. The nuc gene was detected in 86 of 121 staphylococcal isolates examined and named as $S$. aureus. The remaining 35 isolates were identified as Staphylococcus spp.

Antibiotic sensitivity test results: The resistance profiles of the isolates examined in the study are shown in Table 3-5.

Table 3. Antibiotic susceptibility profiles of $S$. aureus isolates.

\begin{tabular}{|c|c|c|c|c|c|c|c|c|}
\hline & VA & TEC & OX & SXT & $\mathrm{TE}$ & PEN-G & CEP & AMC \\
\hline $\mathbf{R}$ & 9 & 16 & 30 & 7 & 20 & 43 & 19 & 35 \\
\hline I & 0 & 10 & 5 & 14 & 16 & 6 & 18 & 6 \\
\hline $\mathbf{S}$ & 77 & 60 & 51 & 65 & 50 & 37 & 49 & 45 \\
\hline \multirow{2}{*}{\multicolumn{9}{|c|}{$\begin{array}{l}\text { S: sensitive; I: Intermediate; R: resistant. VA: vancomycin; TEC: teicoplanin; OX: oxacillin; SXT: } \\
\text { trimethoprim-sulfamethoxazole; TE: tetracycline; PEN-G: penicillin G; CEP: cefoperazone; } \\
\text { AMC: amoxicillin / clavulanic acid } \\
\text { Table 4. Antibiotic susceptibility profiles of Staphylococcus spp. } \\
\text { isolates. }\end{array}$}} \\
\hline & & & & & & & & \\
\hline & VA & TEC & $\mathbf{O x}$ & SXT & TE & PEN-G & CEP & AMC \\
\hline $\mathbf{R}$ & 0 & 1 & 1 & 2 & 0 & 4 & 1 & 3 \\
\hline I & 0 & 2 & 3 & 4 & 3 & 2 & 4 & 1 \\
\hline $\mathbf{S}$ & 35 & 32 & 31 & 29 & 32 & 29 & 30 & 31 \\
\hline
\end{tabular}


Vancomycin resistance level results: MIC values were determined for 9 isolates that were determined to be vancomycin resistant by the disc diffusion technique. As a result of the evaluation, 7 isolates were found to be resistant to $32 \mu \mathrm{g} / \mathrm{ml}$ and 2 isolates to $64 \mu \mathrm{g} / \mathrm{ml}$ vancomycin.

Table 5. Multiple antibiotic resistance profiles of isolates.

\begin{tabular}{ccc}
\hline Number of antibiotics with resistance & S. aureus (n) & Staphylococcus spp. (n) \\
\hline 8 & 9 & 0 \\
7 & 6 & 0 \\
6 & 7 & 0 \\
5 & 9 & 0 \\
4 & 6 & 0 \\
3 & 5 & 2 \\
2 & 11 & 6 \\
1 & 16 & 5 \\
0 & 17 & 22 \\
\hline
\end{tabular}

Genotypic determination of vancomycin resistance: Vancomycin resistance genes of 9 isolates determined to be resistant to vancomycin by disc diffusion method were determined by PCR method. As a result of $\mathrm{PCR}$, it was determined that 2 isolates gave positive band for vanA (1029 bp) and 3 isolates for vanR (645 bp) gene. In 4 isolates resistant to vancomycin, the genes examined could not be determined.

Virulence gene results: coa and spa virulence genes of all $S$. aureus isolates $(\mathrm{n}=86)$ included in the study were determined by PCR method. As a result of PCR performed to detect coa gene, 61 of isolates were found to be positive. The band profiles of the isolates for coa were presented Table 6.

Table 6. Coa polymorphism profiles of S. aureus isolates.

\begin{tabular}{lcc}
\hline Coa group & Band size (bp) & Number of isolates \\
\hline 1 & 950 & 2 \\
2 & 800, and 400 & 3 \\
3 & 550 & 7 \\
4 & 800 & 4 \\
5 & 550, and 500 & 6 \\
6 & 820, and 250 & 3 \\
7 & 250 & 3 \\
8 & 820,620, and 580 & 2 \\
9 & 120 & 31 \\
10 & negative & 25 \\
\hline
\end{tabular}

As a result of PCR with the presence of spa gene, 86 isolates were found to be positive. The band profiles of the isolates for spa were presented in Table 7.

Table 7. Spa polymorphism profiles of $S$. aureus isolates.

\begin{tabular}{lcc}
\hline spa group & Band size $(\mathbf{b p})$ & Number of isolates \\
\hline 1 & 130 & 26 \\
2 & 200 & 31 \\
3 & 290 & 16 \\
4 & 310 & 13 \\
\hline
\end{tabular}

Genotyping and phylogenetic analysis results: As a result of RAPD-PCR for genotyping of vancomycin resistant isolates, 9 different genotypes with a similarity between 51-75\% were detected (Figure 1 and 2).

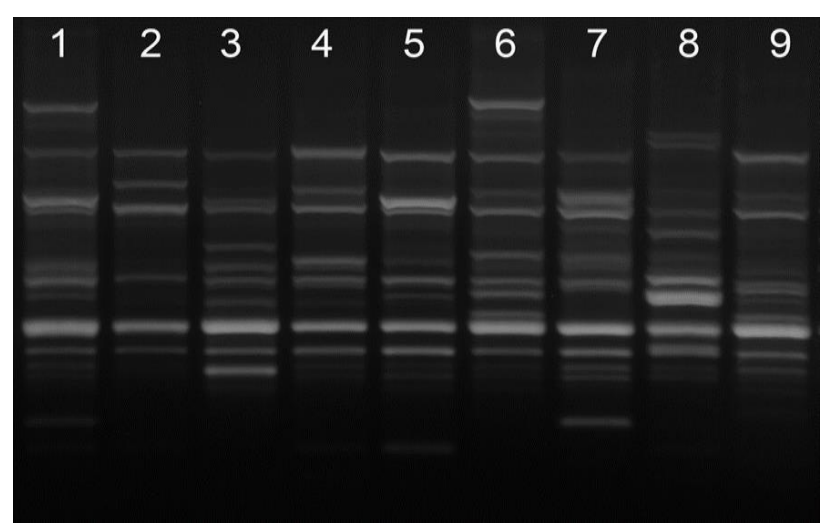

Figure 1. RAPD-PCR profiles of S. aureus isolates.

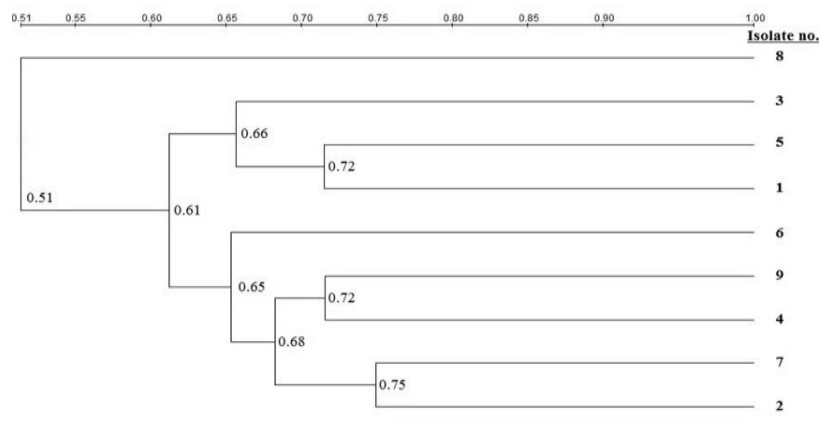

Fig. 2. Phylogenetic proximity analysis of $S$. aureus isolates.

\section{DISCUSSION}

Bovine mastitis is the most costly disease to the dairy industry worldwide as well as in Turkey. S. aureus is an important etiologic agent of mastitis in ruminants and also has an economical importance in cattle industry. There are many enzymes involved in the virulence of staphylococci. Coagulase is an extracellular proenzyme that coagulates the plasma by converting the fibrinogen to fibrin. Detection of this enzyme, which is accepted as a pathogenicity criterion for $S$. aureus, is routinely used to differentiate pathogenic staphylococci. Of the 121 isolates examined in the study, 73 were found to be coagulase positive and all of the positive isolates were $S$. aureus. It was observed that $13 \mathrm{~S}$. aureus examined did not synthesize coagulase enzyme. The expression of the coagulase enzyme depends on the presence of the coa gene, and for this purpose, the presence of coa gene in the $S$. aureus isolates and the polymorphism in the gene were investigated for this purpose. As a result of PCR performed to detect coa gene presence and polymorphism, 61 isolates were found to be positive for coa gene and the remaining 25 isolates were found to be negative. The isolates found to be coa positive were grouped according to the band profiles they showed as a result of polymorphism occurring in the gene and 10 profiles were determined. While 25 of the isolates did not contain the coa gene, 2 isolates produced a band of $950 \mathrm{bp}$. On the other hand, we were determined that formed three isolates 800 and 400 bp 2 
bands, 7 isolates $550 \mathrm{bp}$ single band, 4 isolates $800 \mathrm{bp}$ single band, 6 isolates 550 and 500 bp 2 bands, 3 isolates 820 and 250 bp 2 bands, 3 isolates 250 bp single band, 31 isolates 120 bp single band and 2 isolates formed 820, 620 and $580 \mathrm{bp}$ size 3 bands. These results were found to be compatible with previous study (Karahan \& Çetinkaya, 2007; Xu et al., 2015; Oliveira et al., 2016) data indicating that polysorphisms in terms of coa gene in mastitis isolate bacteria show that this shows diversity in mastitis isolate $S$. aureus.

The colonization process of $S$. aureus begins with its attachment to the host cell surface, and this takes place through the adhesins contained in the bacteria. Most of the adhesins contained in $S$. aureus are proteins found in cell peptidoglycans called Protein A (spa). Protein A is used as an important reagent in immunology and diagnostic laboratory technology for its properties such as binding to the Ig molecule and agglutinating bacteria against specific bacterial antigens. The gene responsible for the synthesis of protein A is the spa gene. As a result of the study, 86 gene isolates were found positive in terms of spa gene presence and PCR after polymorphism of isolates identified as $S$. aureus. It was determined that the isolates carrying the spa gene formed a band of different sizes and thus showed polymorphism in 4 different groups. It was seen that 26 of the isolates were $130 \mathrm{bp}, 31$ were $200 \mathrm{bp}$, 16 were $290 \mathrm{bp}$ and 13 were $310 \mathrm{bp}$. As a result, it was determined that all mastitis isolates $S$. aureus carry the spa gene but there are polymorphisms in terms of gene. As this, spa genes are also common in several other studies on bovine mastitis, it can be assumed that these genotypes are prevalent among dairy cows (Schabauer et al., 2018; Pichette-Jolette et al., 2019)

The discovery of effective agents used in the treatment of infections caused by pathogenic bacteria is considered one of the most important developments in modern medicine. Like many other bacterial agents, there are antibiotics that staphylococci are resistant. Staphylococcus strains resistant to antibiotics cause problems in the treatment of bovine mastitis as in other diseases (Schwarz et al., 2018). There are many studies (Guimarães et al., 2017; Haubert et al., 2017; Sezener et al., 2019) showing that resistance to most antibiotics such as methicillin, vancomycin, used in the treatment of cattle mastitis of staphylococcal origin has developed over time.

In this study, $S$. aureus isolates were found to be resistant at penicillin G, amoxicillin/clavulanic acid, oxacillin, tetracycline, cefoperazone, teicoplanin, vancomycin and trimethoprim- sulfamethoxazole 50\% (43/86), 40.7\% (35/86), 34.9\% (30/86), 23.3\% (20/86), $22.1 \%(19 / 86), 18.6 \%(16 / 86) 10.5 \%(9 / 86)$ and $8.1 \%$ (7/86) respectively. On the other hand, $4(11.4 \%)$ of 35 Staphylococcus spp. isolates were resistant to penicillin G,
$3(8.6 \%)$ to amoxicillin/clavulanic acid, $2(5.7 \%)$ to trimethoprim- sulfamethoxazole, $1(2.9 \%)$ to oxacillin, cefoperazone, teicoplanin, while all isolates were sensitive to vancomycin and tetracycline. Penicillin resistance is probably the best known antimicrobial resistance property of $S$. aureus and its frequency in the current study is in accordance with other studies that examined antibiotic susceptibility patterns of staphylococci isolated from cases of bovine mastitis. Resistance to penicillin among $S$. aureus from bovine mastitis has been encountered with increasing frequency throughout the world. However, the reported prevalence rates have varied extensively in different geographical regions. The percentage of penicilin resistant S. aureus isolates was found to be as high as $87 \%$ in China (Shi et al., 2010), 61\% in Estonia (Kalmus et al., 2011), 50\% in Turkey (Sezener et al., 2019), 45.3\% in Kenya (Antok et al., 2020), 41\% in Poland (Jagielski et al., 2014) $25 \%$ in 9 country cited by vetpath study group (de Jong et al., 2018).

Besides, MIC values of vancomycin-resistant $S$. aureus isolates were determined as $32 \mu \mathrm{g} / \mathrm{ml}$ for 7 isolates and $64 \mu \mathrm{g} / \mathrm{ml}$ vancomycin resistant (VRSA) for 2 isolates. Of the $9 \mathrm{~S}$. aureus isolates that were phenotypically resistant to vancomycin, vanA gene (1029 bp) was detected in 2 and vanR gene (645 bp) in 3. In 4 isolates resistant to vancomycin, the genes examined could not be determined. Multiple resistance to three or more antibiotics was determined in many of $S$. aureus isolates $(48.8 \%, 42 / 86)$. It was determined that S.aureus isolates were resistant to 8 , $7,6,5,4,3,2$ and 1 antibiotics at $10.47 \%, 6.98 \%, 8.14 \%$, $10.47 \%, 6.98 \%, 5.81 \%, 12.79 \%$ and $18.60 \%$ respectively. Seventeen isolates were also found to be sensitive to tested antibiotics. This shows the emergence of antimicrobial resistance in $S$. aureus isolated from bovine mastitis samples in Turkey. Recently, an increase in the number of antimicrobial resistant bacteria from bovine mastitis has been recognized, similar to the results obtained in this study (de Jong et al., 2018; Sezener et al., 2019). When evaluated in terms of multiple resistance, $5.71 \%$ of the Staphylococcus spp. isolates were found resistant to 3 antibiotics, $5.71 \%$ to 2 antibiotics and $17.14 \%$ to 1 antibiotic. Twenty-two isolates were found to be sensitive to all antibiotics tested. Multiple antibiotic resistance was found to be higher in $S$. aureus compared to other staphylococci. As a result, it was concluded that due to its multiple antibiotic resistance, mastitis originated $S$. aureus posed a risk both in the treatment of the animal and in terms of public health.

Molecular typing of bacterial isolates is done due to variations in chromosomal DNA structure (Goh et al., 1992; Carter et al., 2003). As with other bacterial species, Staphylococcus strains have many subtypes. Accurate identification of clones with high virulence or 
epidemiologically spreading is considered important (Frenay et al., 1994; Frenay et al., 1996). Molecular typing systems have many advantages such as high performance and easy applicability compared to conventional methods. Although Pulsed-Field Gel Electrophoresis (PFGE), which is one of the molecular typing methods, is accepted as the "golden standard", PCR-based methods are frequently used for their quick results, ease and economy (Sabat et al., 2006). RAPD-PCR typing, which is one of the PCR based methods, is a typing method based on the principle of replicating DNA in short sections under the primer and variable reaction conditions that are randomly bound to DNA. This method is often used to determine genetic affinities among the isolates. It provides comparison of bacterial species depending on the regions to which the primer is attached (Qu et al., 2019).

Correct and fast typing of staphylococci is important in controlling the infection (Hookey et al., 1998). There are many subtypes of staphylococci, especially $S$. aureus, that vary depending on their virulence genes (DaSilva et al., 2006). Determining the genetic variation and heterogeneity in these bacteria is important for determining rational and effective strategies for staphylococci that cause mastitis (Kapur et al., 1995). In this study, as a result of RAPD-PCR performed using the M13 primer for genotyping of vancomycin resistant 9 isolates, 9 different genotypes with a similarity between $51-75 \%$ were detected. This detected diversity showed that there was diversity in mastitis-derived S.aureus strains and the clones causing infection were not closely related. Similar results were reported in other studies, with 2 predominant RAPD types of 6 representing 71\% (Wang et al., 2016) and 60\% (Qu et al., 2019) S. aureus isolates. Therefore, particular S. aureus strains might transmit more from cow to cow.

In conclusion, multiple antibiotic resistance rates in $S$. aureus isolates investigated were found to be important for mastitis treatment. The results obtained from this study show that milk and dairy products containing these factors pose a public health risk due to the determination of vancomycin resistance in mastitis-derived Staphylococcus strains. Very close genetic relationship could not be detected in Staphylococcus isolates isolated from bovine mastitis. This status indicates that there is a polymorphism genotypically among the isolates. Further studies are needed with Staphylococcal isolates from cattle with more mastitis.

\section{ACKNOWLEDGEMENTS}

This study was supported by the Ondokuz Mayıs University Scientific Research Projects Commission with the project number of PYO.VET.1904.14.005.

\section{REFERENCES}

Antok, F.I., Mayrhofer, R., Marbach, H., Masengesho, J.C., Keinprecht, H., Nyirimbuga, V., Fischer, O., Lepuschitz, S., Ruppitsch, W., EhlingSchulz, M., Feßler, A.T., Schwarz, S., Monecke, S., Ehricht, R., Grunert, T., Spergser, J. \& Loncaric, I. (2020). Characterization of antibiotic and biocide resistance genes and virulence factors of Staphylococcus species associated with bovine mastitis in Rwanda. Antibiotics (Basel), 9, 1.

Carter, P.E., Begbie, K., \& Thomson, F.M. (2003). Coagulase gene variants associated with distinct populations of Staphylococcus aureus. Epidemiology and Infection, 130, 207-219.

Centers for Disease Control and Prevention (CDCP). (1997). Staphylococcus aureus with reduced susceptibility to vancomycin-United States. MMWR, 46, 765-766.

Ciftci, A., Findik, A., Onuk, E. E. \& Savasan, S. (2009). Detection of methicillin resistance and slime factor production of Staphylococcus aureus in bovine mastitis. Brazilian Journal of Microbiology, 40, 254-261.

Clinical and Laboratory Standards Institute (CLSI). (2018). Performance standards for antimicrobial disk and dilution susceptibility tests for bacteria isolated from animals, Approved Standard; CLSI Document VET08, 4th ed. Clinical and Laboratory Standards Institute, Wayne, PA, USA.

DaSilva, E.R., Boechat, J.U.D. \& DaSilva, N. (2006). Coagulase gene polymorphism of Staphylococcus aureus isolated from goat mastitis in Brazilian dairy herds. Letters in Applied Microbiology, 42, 30-34.

de Jong, A., El Garch, F., Simjee, S., Moyaert, H., Rose, M., Youala, M. \& Siegwart, E. (2018). Monitoring of antimicrobial susceptibility of udder pathogens recovered from cases of clinical mastitis in dairy cows across Europe: VetPath results. Veterinary Microbiology, 213, 73-81.

Dezfulian, A., Aslani, M.M., Oskoui, M., Farrokh, P., Azimirad, M., Dabiri, H., Salehian, M.T. \& Zali, MR. (2012). Identification and characterization of a high vancomycin-resistant Staphylococcus aureus harboring vanA gene cluster isolated from diabetic foot ulcer. Iranian Journal of Basic Medical Science, 15, 803-806.

Findik, A., Ica, T., Onuk, E.E., Percin, D., Kevenk, T.O. \& Ciftci, A. (2011). Molecular typing and $c d t$ genes prevalence of Campylobacter jejuni isolates from various sources. Tropical Animal Health and Production, 43, 711-719.

Frenay, H.M.E., Theelen, J.P.G. \& Schouls, LM. (1994). Discrimination of epidemic and nonepidemic methicillin-resistant Staphylococcus aureus strains on the basis of protein A gene polymorphism. Journal of Clinical Microbiology, 32, 846-847. 
Frenay, H.M.E., Bunschoten, A.E. \& Schouls, L.M. (1996). Molecular typing of methicillin-resistant Staphylococcus aureus on the basis of protein A gene polymorphism. European Journal of Clinical Microbiology and Infectious Diseases, 15, 60-64.

Goh, S.H., Byrne, S.K., Zhang, J.L. \& Chow, A.W. (1992). Molecular typing of Staphylococcus aureus on the basis of coagulase gene polymorphisms. Journal of Clinical Microbiology, 30, 1642-1645.

Guimarães, F.F., Manzi, M.P., Joaquim, S.F., RichiniPereira, V.B. \& Langoni, H. (2017). Short communication: Outbreak of methicillin-resistant Staphylococcus aureus (MRSA)-associated mastitis in a closed dairy herd. Journal of Dairy Science, 100, 726-730.

Hartstein, A.I. \& Mulligan, M.E. (1986). Methicillinresistant Staphylococcus aureus. In: Glen Mayhall C, ed. Hospital epidemiology and infection control. Maryland: Williams and Wilkins, 290-306.

Haubert, L., Kroning, I.S., Iglesia, M.A., \& da Silva, W.P. (2017). First report of the Staphylococcus aureus isolate from subclinical bovine mastitis in the South of Brazil harboring resistance gene $d f r G$ and transposon family Tn916-1545. Microbial Pathogenesis, 113, 242-247.

Hiramatsu, K., Hanaki, H., Ino, T., Yabuta, K., Oguri, T. \& Tenover, F.C. (1997). Methicillin- resistant Staphylococcus aureus clinical strain with reduced vancomycin susceptibility. Journal of Antimicrobial Chemotherapy, 40, 135-136.

Hookey, J.V., Richardson, J.F. \& Cookson, B.D. (1998). Molecular typing of Staphylococcus aureus based on PCR Restriction Fragment Length Polymorphism and DNA sequence analysis of the coagulase gene. Journal of Clinical Microbiology, 36, 1083-1089.

Jagielski, T., Puacz, E., Lisowski, A., Siedlecki, P., Dudziak, W., Miedzobrodzki, J. \& Krukowsk, H. (2014). Short communication: Antimicrobial susceptibility profiling and genotyping of Staphylococcus aureus isolates from bovine mastitis in Poland. Journal of Dairy Science, 97, 6122-6128.

Jevons, M.P. (1961). Celbenin-resistant staphylococci. British Medical Journal, 1, 124-125.

Kaatz, G., Seo, S.M., Dorman, N.J. \& Lerner, S.A. (1990). Emergence of teicoplanin resistance during therapy of Staphylococcus aureus endocarditis. Journal of Infectious Diseases, 162, 103-108.

Kalmus, P., Aasmäe, B., Kärssin, A., Orro, T. \& Kask, K. (2011). Udder pathogens and their resistance to antimicrobial agents in dairy cows in Estonia. Acta Veterinaria Scandinavica, 53, 4.

Kapur, V., Sischo, W.M. \& Greer, R.S. (1995). Molecular population genetic analysis of Staphylococcus aureus recovered from cows. Journal of Clinical Microbiology, 33, 376-380.
Karahan, M. \& Çetinkaya, B. (2007). Coagulase gene polymorphisms detected by PCR in Staphylococcus aureus isolated from subclinical bovine mastitis in Turkey. The Veterinary Journal, 174, 428-431.

Kot, B., Szweda, P., Frankowska-Maciejewska, A., Piechota, M. \& Wolska, K. (2016). Virulence gene profiles in Staphylococcus aureus isolated from cows with subclinical mastitis in eastern Poland. Journal of Dairy Research, 83, 228-235.

Momtaz, H., Rahimi, E. \& Tajbakhsh, E. (2010). Detection of some virulence factors in Staphylococcus aureus isolated from clinical and subclinical bovine mastitis in Iran. African Journal of Biotechnology, 25, 3753-3758.

Monistero, V., Barberio, A., Biscarini, F., Cremonesi, P., Castiglioni, B., Graber, H.U., Bottini, E., Ceballos-Marquez, A., Kroemker, V., Petzer, I.M., Pollera, C., Santisteban, C., Dos Santos, M.V., Bronzo, V., Piccinini, R., Re, G., Cocchi, M. \& Moroni, P. (2020). Different distribution of antimicrobial resistance genes and virulence profiles of Staphylococcus aureus strains isolated from clinical mastitis in six countries. Journal of Dairy Science, 103, 3431-3446.

Oliveira, C.J.B., Tiao, N., de Sousa, F.G.C., de Moura, J.F.P., Santos Filho, L. \& Gebreyes, W.A. (2016). Methicillin-Resistant Staphylococcus aureus from Brazilian Dairy Farms and Identification of Novel Sequence Types. Zoonoses and Public Health, 63, 97-105.

Pichette-Jolette, S., Millette, G., Demontier, E., BranBarrera, D., Cyrenne, M., Ster, C., Haine, D., Keefe, G., Malouin, F. \& Roy, JP. (2019). Partial prediction of the duration and the clinical status of Staphylococcus aureus bovine intramammary infections based on the phenotypic and genotypic analysis of isolates. Veterinary Microbiology, 228, 188-195.

Qu, Y., Zhao, H., Nobrega, D.B., Cobo, E.R., Han, B., Zhao, Z., Li, S., Li, M., Barkema, H.W. \& Gao, J. (2019). Molecular epidemiology and distribution of antimicrobial resistance genes of Staphylococcus species isolated from Chinese dairy cows with clinical mastitis. Journal of Dairy Science, 102, 1571-1583.

Sabat, A., Malachowa, N., Miedzobrodzki, J. \& Hryniewicz, W. (2006). Comparison of PCRbased methods for typing Staphylococcus aureus isolates. Journal of Clinical Microbiology, 44, 3804-3807.

Schabauer, A., Pinior, B., Gruber, C.M., Firth, C.L., Käsbohrer, A., Wagner, M., Rychli, K. \& Obritzhauser, W. (2018). The relationship between clinical signs and microbiological species, spa type, and antimicrobial resistance in bovine mastitis cases in Austria. Veterinary Microbiology, 227, 52-60.

Schmitz, F.J. \& Jones, M.E. (1997). Antibiotics for treatment of infections caused by MRSA and elimination of MRSA carriage. What are the 
choices? International Journal of Antimicrobial Agents, 9, 1-19.

Schwalbe, R., Stapleton, J.T. \& Gilligan, P.H. (1987). Emergence of vancomycin resistance in coagulase negative staphylococci. New England Journal of Medicine, 316, 927-931.

Schwarz, S., Feßler, A.T., Loncaric, I., Wu, C., Kadlec, K., Wang, Y. \& Shen, J. (2018). Antimicrobial resistance among staphylococci of animal origin. Microbiol Spectrum, 6, ARBA-0010-2017.

Sezener, M.G., Findık, A., Erguden, V.E., Akgoz, S., Gulhan, T. \& Ciftci, A. (2019). The determination of antibiotic resistances and some virulence genes of Staphylococcus aureus isolated from bovine mastitis. Journal of Anatolian Environmental and Animal Sciences, 4, 182-187.

Shi, D., Hao, Y., Zhang, A., Wulan, B. \& Fan, X. (2010). Antimicrobial resistance of Staphylococcus aureus isolated from bovine mastitis in China. Transboundary Emerging Diseases, 57, 221-224.

Wang, D., Zhang, L., Zhou, X., He, Y., Yong, C., Shen, M., Szenci, O. \& Han, B. (2016). Antimicrobial susceptibility, virulence genes, and randomly amplified polymorphic DNA analysis of Staphylococcus aureus recovered from bovine mastitis in Ningxia, China. Journal of Dairy Science, 99, 9560-9569.

Xu, J., Tan, X., Zhang, X., Xia, X. \& Sun, H. (2015). The diversities of staphylococcal species, virulence and antibiotic resistance genes in the subclinical mastitis milk from a single Chinese cow herd. Microbial Pathogenesis, 88, 29-38. 